\title{
Potential allelopathic effects of rice plant aqueous extracts on germination and seedling growth of some rice field common weeds
}

\author{
Md. Amirul Alam, ${ }^{1}$ M.A. Hakim, ${ }^{2}$ Abdul Shukor Juraimi, ${ }^{3}$ M.Y. Rafii, ${ }^{2,3}$ M.M. Hasan, ${ }^{2}$ \\ Farzad Aslani ${ }^{3}$ \\ ${ }^{1}$ Faculty of Sustainable Agriculture, Horticulture and Landscaping Program, University Malaysia Sabah, \\ Sandakan Campus, Sandakan, Sabah; ${ }^{2}$ Institute of Tropical Agriculture and Food Security, University \\ Putra Malaysia, UPM Serdang, Selangor; ${ }^{3}$ Department of Crop Science, Faculty of Agriculture, University \\ Putra Malaysia, UPM Serdang, Selangor, Malaysia
}

\begin{abstract}
Given the increasing emphasis on sustainable agriculture, and concerns about the adverse effects of extensive use of farm chemicals, research attention is now being focused on reducing the dependence upon synthetic herbicides, and finding alternative strategies for weed management. Allelopathic properties of crop plants may allow us to use lower amounts of herbicides with benefits for the environment and human health. Considering these aspects, the present study was conducted to investigate the allelopathic effects of six selected rice varieties (WITA-3, WITA-4, WITA-12, Woo-Co, Fukuhibiki and Kalizira) collected from Bangladesh Rice Research Institute (BRRI) on seed germination and seedling growth of five weed species; Echinochloa crus-galli, Cyperus difformis, Cyperus iria, Fimbristylis milliacea and weedy
\end{abstract}

Correspondence: Md. Amirul Alam, Faculty of Sustainable Agriculture, Horticulture and Landscaping Program, University Malaysia Sabah, Sandakan Campus, Sandakan 90509, Sabah, Malaysia; and Abdul Shukor Juraimi, Department of Crop Science, Faculty of Agriculture, University Putra Malaysia, UPM Serdang, Selangor, DE 43400, Malaysia.

E-mail: amirulalam@unisza.edu.my and ashukor@agri.upm.edu.my

Key words: Allelopathic potentials; aqueous extract; rice cultivars; weeds species; germination; seedling growth.

Acknowledgements: the authors sincerely acknowledge Fundamental Research Grant Scheme (FRGS), UPM for financial support, University Putra Malaysia for providing all the supports and facilities for conducting this experiment and Bangladesh Rice Research Institute (BRRI) for providing rice seeds.

Conflict of interest: the authors declare no conflict of interests.

Received for publication: 13 July 2017

Revision received: 28 November 2017.

Accepted for publication: 2 December 2017.

CCopyright M.A. Alam et al., 2018

Licensee PAGEPress, Italy

Italian Journal of Agronomy 2018; 13:1066

doi:10.4081/ija.2018.1066

This article is distributed under the terms of the Creative Commons Attribution Noncommercial License (by-nc 4.0) which permits any noncommercial use, distribution, and reproduction in any medium, provided the original author(s) and source are credited. rice. The aqueous extracts of all the rice cultivars caused inhibitory effects on seed germination and seedling shoot-root length of all the weed species. However, the inhibitory effects of different rice varieties varied significantly based on the differences of weed species and weedy rice found to be the least affected compared to other weeds. WITA-12 resulted about 50\% germination inhibition, $25 \%$ shoot length reduction and $23 \%$ root length reduction respectively compared to control. On the basis of average percentage inhibition, rice varieties ranked in order; WITA-12>WITA$4>$ Fukuhibiki $>$ Kalizira $>$ Woo-Co $>$ WITA-3. Our results suggested that there is a possibility of developing a new ecological weed management strategy using rice cultivars with higher allelopathic potentials. This means breeding of rice cultivars with higher allelopathic potential may provide natural and sustainable weed management options for rice growers.

\section{Introduction}

Rice (Oryza sativa L.) is the staple food for more than half of the world population with at least two billion people in Asia, especially in South and Southeast Asia and Latin America (FAOSTAT, 2012; Amb and Ahluwalia, 2016). It is the third most important crop in Malaysia, grown mainly in eight granaries in Peninsular Malaysia covering an area of about 205,548 ha (Azmi and Mashhor, 1995; MOA, 2007). Globally weed is a major constraint in rice production (Hakim et al., 2014). Weeds have been a persistent problem for farmers since the beginning of agriculture causing economic losses to farmers by increasing cost of crop production, and reducing crop yield and quality (Abouziena and Haggag, 2016). Weed control in any crop should be dependent firstly on the crop rotation then on the tillage practices used and later on the crop as the competitor. There are many tactics in use to control weeds: mechanical, physical, cultural, biological and chemical methods. The chemical weed control method is popular in reducing the negative effects of weeds in crop fields. Herbicides are easy to use and chiefly synthesised for weed management (Naylor, 1996). The consequent widespread uses of the herbicides for rice production are of serious environmental concern for their potentials to pollute drinking water, fish, and others. So, concerns about negative effects of herbicide uses, such as environmental contamination, development of herbicide-resistant weeds, and human health problems pave the way to find diversified weed management options (Holethi et al., 2008). Therefore, an alternative weed control system is obviously desirable exploiting naturally occurring plant inhibitors in the scientific and economic manners.

Allelopathy is an ecological phenomenon in which chemicals 
produced and released from a plant affect the germination or growth of another plant (Cheng and Cheng, 2015; Trezzi et al., 2016). The possible exploitation of allelopathy is the use of allelopathic cover crops for weed management. However, during the past ten years; the research methodologies have mainly focused on generating information about chemistry, occurrence, and modes of synthesis of the allelopathy. Now, abundant information exists about this complex area of biology; and many naturally occurring allelochemicals have been isolated and characterised. A number of higher plants are also observed to possess allelopathic potential (Hong et al., 2003; Aslani et al., 2015; Abouziena and Haggag, 2016). About four percentage of the rice cultivars have demonstrated allelopathic potential against some of the most troublesome weed species in rice fields: barnyardgrass (Echinochloa crusgalli), redstem (Ammannia spp.), sedge (Cyperus spp.) and ducksalad (Heteranthera limosa) (Asghari et al., 2006; Aslani et al., 2014). Allelopathy directly influences the release of one chemical from a plant and influences the growth and development of others in its environment, and may provide an alternative but promising weed control method (Trezzi et al., 2016). Limited works have been done worldwide in respect of weed management, especially on natural weed management by plant allelopathic potentials.

The use of allelopathic behaviour of the rice crop is one of the new options for sustainable weed management (Amb and Ahluwalia, 2016). Many allelochemicals are secondary plant metabolites including alkaloids, phenolics, flavonoids, terpenis, glucosionlates, etc. are synthesised by plants during their growth and development (Tabaglio et al., 2008; Trezzi et al., 2016). Several authors analysed to evaluate the allelopathy of plants on weeds in agricultural field (Duke et al., 2000; Bi et al., 2007). Organic farming systems can utilise allelopathy as the alternative to synthetic herbicides and conventional farming can effectively reduce the reliance on the pre-emergence herbicides (Jabran, 2017). But unfortunately, research in allelopathy did not receive the adequate attention it deserved. Much research works have focused on ubiquitous weeds such as Cyperus difformis (Chopra et al., 2017) and Echinochloa crus-galli (Kato-Noguchi et al., 2008; Guo et al., 2017). However, the allelopathic potential of rice cultivars against the vital rice field weeds, which grow in close association of rice, remains to be studied. Every year, huge man power and agrochemicals are spent to control luxuriantly growing dominant rice field weeds viz. Echinochloa crus-galli, Cyperus difformis, Cyperus iria, Fimbristylis milliacea and weedy rice in paddy fields of Peninsular Malaysia. Through selection/development of appropriate rice varieties with proper allelopathic properties, could be an economically viable and sustainable weed management option for these noxious rice field weeds. However, very few systematic works have been done on the weed control by rice allelopathy in Peninsular Malaysia and fewer published information on the effect of rice allelopathy for weed control techniques are available. Therefore, it is vital to develop appropriate techniques for successful and sustainable weed management method in the rice field of Malaysia utilising the allelopathic potential of rice plants. The basic approach used in allelopathic research for agricultural crops has been to screen crop plants for their capacity to suppress weeds. To determine allelopathic property in the laboratory for a particular crop species, plant extracts and leachates are commonly screened for their effects on weed seed germination and weed seedling growths with further isolation and identification of allelochemicals through greenhouse and field trials, confirming the laboratory results. In this study, aqueous extracts of some rice varieties were used to investigate their allelopathic effects on seed germination and seedling growth of some rice field common weeds.

\section{Materials and methods}

\section{Collection of weed seeds}

Seeds of five weed species; Echinochloa crus-galli, Cyperus difformis, Cyperus iria, Fimbristylis milliacea and weedy rice (Oryza sativa) were collected from rice fields located in Tanjung Karang areas of Malaysia. The seeds were cleaned, properly dried and stored in laboratory refrigerator at $4^{\circ} \mathrm{C}$ temperature until used. Before setting up the experiment the weed seeds were then sundried for one hour to break the cold dormancy and kept for another one hour in room temperature.

\section{Preparation of the aqueous extracts}

Six rice (Oryza sativa L.) varieties (collected from BRRI, Bangladesh: T1: WITA 3, T2: WITA 4, T3: WITA 12, T4: Fukuhibiki, T5: Woo-Co and T6: Kalizira) were grown at the glasshouse, University Putra Malaysia. Before panicle initiation collected leaves with stem from those rice cultivars were dried at $28^{\circ} \mathrm{C}$, ground in a laboratory grinding mill and $50 \mathrm{~g}$ ground powdered tissue of each variety was soaked in $500 \mathrm{~mL}$ distilled water for $24 \mathrm{~h}$ at room temperature. The tissue and water mixture were then shaken for $48 \mathrm{~h}$ in laboratory conditions and the extracts was filtered through four layers of cheesecloth. The filtrate was centrifuged at $3000 \mathrm{rpm}$ for $4 \mathrm{~h}$. The supernatant was isolated through on layer of Whatman No. 42 filter paper. After that, the refined extracts were preserved in a refrigerator at $4{ }^{\circ} \mathrm{C}$. These extracts were designated as $10 \%(\mathrm{w} / \mathrm{v})$ stock solution.

\section{Experimental site, design and treatments}

A series of laboratory experiments were conducted with the aqueous extracts of rice and the five weed species separately at Weed Science Laboratory, University Putra Malaysia since February 2015 to January 2016. The germination test was carried out in sterile Petri dishes ( $9 \mathrm{~cm}$ dia.) lined with two filter papers Whatman No. 3. The different rice plant extracts were added to every Petri dish of the respective treatments daily in amounts just to keep the seeds moist enough to get favourable conditions for germination and growth. The control treatment was treated with distilled water only. Before setting for germination test, the weed seeds were surface sterilised with $1 \%$ sodium hypochlorite $(\mathrm{NaOCl})$ for $3 \mathrm{~min}$ and rinsed thoroughly with distilled water. The experiment was arranged in the completely randomised design with three replications. Twenty seeds were placed in each Petri dish. The Petri dishes were set in the Weed Science Laboratory, University Putra Malaysia (UPM) at the room temperature ranging from $28-30^{\circ} \mathrm{C}$. A seed was considered germinated when its radical emerged.

\section{Data collection}

The germinated seeds were counted daily and recorded up to 21 days (ISTA, 1999). After nine days, seedling root and shoot lengths were measured. Final germination percentage and mean germination time (MGT) were calculated using the following formulae (Ellis and Robert, 1981):

FGP $=\frac{\text { Number of final germinated seeds }}{\text { Total number of seed tested }} \times 100$ 


$$
\text { MGT }=\frac{\sum \mathrm{Dn}}{\sum \mathrm{n}}
$$

Where, $\mathrm{n}$ is the number of seeds germinated on day $\mathrm{D}$, and $\mathrm{D}$ is the number of days counted from beginning of germination. It is expressed in days.

The time to $50 \%$ germination $\left(\mathrm{T}_{50}\right)$ was calculated according to Farooq et al. (2006):

$\mathrm{T}_{50}=\mathrm{ti}+\frac{\left(\frac{N}{2}-\mathrm{ni}\right)(\mathrm{tj}-\mathrm{ti})}{\mathrm{nj}-\mathrm{ni}}$

where, $\mathrm{N}$ is the final number of germination and $\mathrm{n}_{\mathrm{i}}, \mathrm{n}_{\mathrm{j}}$ are cumulative numbers of seeds germinated by adjacent counts at time $t_{i}$ and $\mathrm{t}_{\mathrm{j}}$ (days) when $\mathrm{n}_{\mathrm{i}}<\mathrm{N} / 2<\mathrm{n}_{\mathrm{j}}$. It is expressed in days.

The percentage (\%) reduction of shoot and root length of weed species due to the allelopathic effect of aqueous rice extracts were calculated using the following formula:

\section{$\%$ of shoot and root growth redcution $=$ \\ $\underline{\text { Control treatment value-Aqueous extrracts treatment value }} \times 100$}

\section{Statistical analysis}

The laboratory experiment was repeated twice to ensure consistency of results. All data were analysed by analysis of variance procedure (ANOVA) and means were separated by least significant difference at the 5\% probability level using Statistical Analysis System software (SAS version 9.3, 2013).

\section{Results and discussion}

\section{Weed seed germination}

The analysis of variance revealed varied differences in germination performances among all five weed species even in the control treatments; having the highest germination in weedy rice $(100 \%)$ and the lowest germination (65\%) in Fimbristylis milliacea weed seeds (Figure 1). The applied aqueous extracts of different rice cultivars also significantly $(\mathrm{P} \leq 0.001)$ affected the overall germination of all the weed species (Table 1 and Figure 1). Very promisingly in case of Cyperus iria, a complete stoppage (100\%) of germination was observed in all the treatments except the control (Table 1). In control treatments, always the highest germinations were noted in case of all the weed species compared to any other treatments which clearly demonstrated the suppressive influence or allelopathic potential of rice aqueous extracts on germination of those weed species. Considering treatments; in T1 (WITA$3)$ the highest reduction in germination $(9.66 \pm 1.15,49.16 \%)$ was observed in case of Cyperus difformis followed by Echinochloa crus-galli $(9.33 \pm 2.51 ; 33.36 \%)$, Fimbristylis milliacea $(9.67 \pm 1.52$, $25.62 \%)$ and weedy rice $(17.67 \pm 1.5,11.65 \%)$ respectively, compared to control (Table 1). Whereas for T2 (WITA-4) the highest reduction of germination $(6.33 \pm 2.08,54.79 \%)$ was observed in Echinochloa crusgalli and the lowest germination (19.33 \pm 1.15 , $3.35 \%$ ) was recorded in weedy rice compared to control (Table 1). In case of T3 (WITA-12) the highest germination reduction was noted in Cyperus difformis $(7.67 \pm 1.53,59.63 \%)$ followed by Echinochloa crusgalli $(7.0 \pm 1.0 ; 50.0 \%)$, Fimbristylis milliacea $(6.66 \pm 1.52,48.57 \%)$ and weedy rice $(18.67 \pm 1.52,6.65 \%)$ respectively, compared to control (Table 1). In T4 (Woo-Co) Fimbristylis milliacea $(9.0 \pm 2.0,30.77 \%)$ was the highest affected weeds for germination followed by Echinochloa crusgalli (10.0 \pm 1.0 ;

$\square$ Weedy rice ${ }^{\circ}$ Cyperus difformis $\boxminus$ Echinochloa crusgalli $\square$ Cyperus iria $\square$ Fimbristylis milliacea

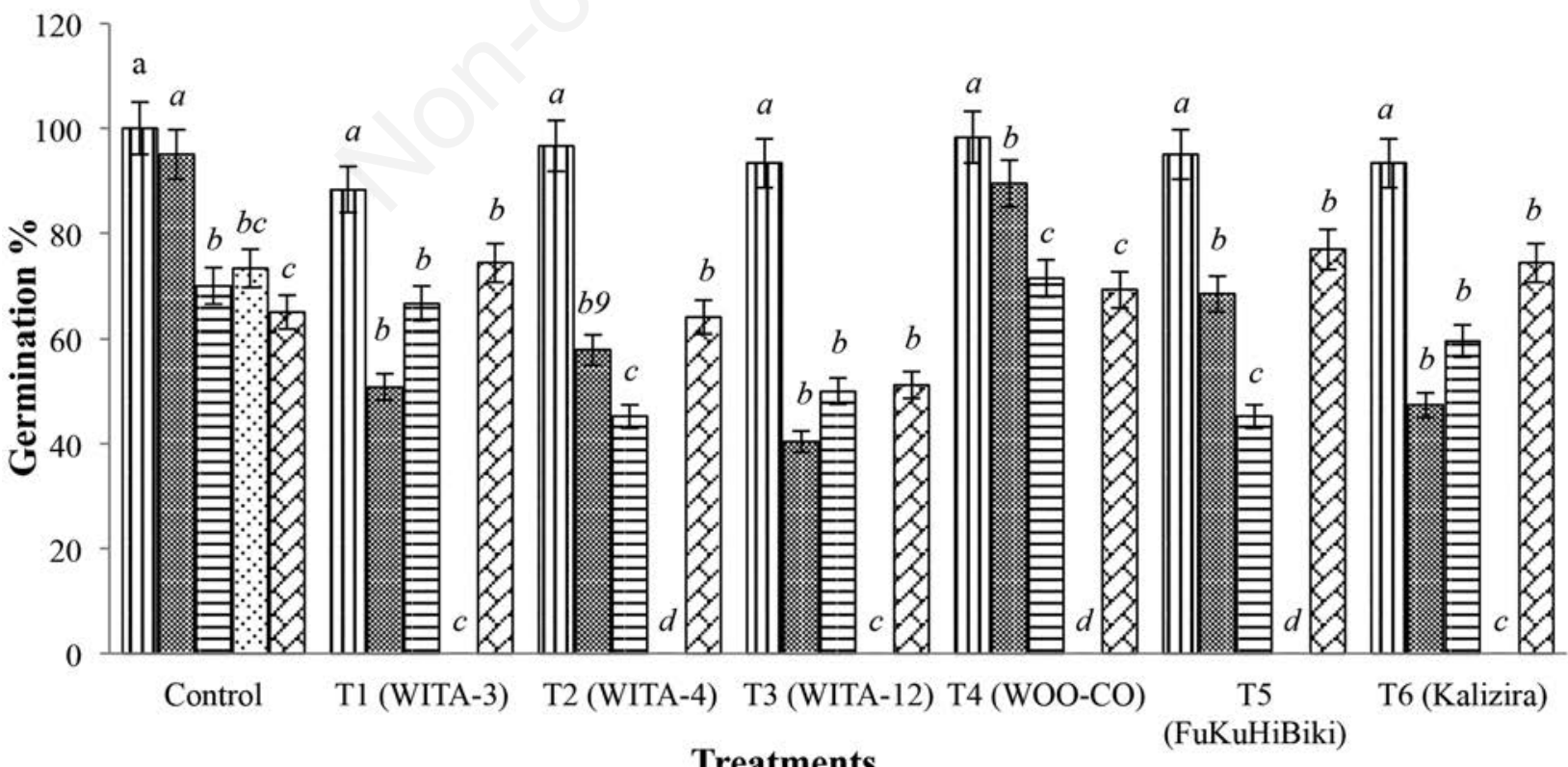

Figure 1. Effect of rice aqueous extract on final germination percentage of weed species. 
$28.57 \%$ ) and the lowest reduction of germination was seen in weedy rice $(19.66 \pm 0.58,1.70 \%)$ compared to control (Table 1). While in T5 (Fukuhibiki) the highest germination reduction $(6.33 \pm 2.52,54.79 \%)$ was also found in Echinochloa crusgalli as well as the lowest in weedy rice $(19.0 \pm 1.0,15.0 \%)$ compared to control (Table 1). Finally, in T6 (Kalizira) the highest suppression of germination was found in Cyperus difformis $(9.0 \pm 1.52,52.63 \%)$ followed by Echinochloa crus-galli (8.33 $\pm 0.58 ; 40.50 .0 \%)$, Fimbristylis milliacea $(9.67 \pm 2.08,25.62 \%)$ and weedy rice $(18.67 \pm 1.5,6.65 \%)$ respectively, compared to control (Table 1). On an average, among all six aqueous extract treatments T3 (WITA-12) showed the highest germination reduction $(50.41 \%)$ followed by, T2 (WITA-4, 44.22\%), T6 (Kalizira, 43.38\%), T1 (WITA-3, 42.56\%), T5 (Fukuhibiki, 40.08\%) and T4 (Woo-Co, $30.99 \%$ ) respectively, over control (Table 1). Our results suggested the phyto-toxicity of allelopathic plant aqueous extracts against the seed germination of different weeds. Naderi and Bijanzadeh (2012) reported about $45 \%$ germination reduction of Echinochloa crus-galli weed seeds by the allelopathic effect of leaf, stem and root aqueous extracts of some Iranian rice (Oryza sativa L.) cultivars. Jafari et al. (2011) also demonstrated 88\% germination reduction of Barnyard Grass by the extract from one local rice cultivar of Iran.

\section{Mean germination time}

Increase in MGT is indicative of delayed germination by the treatment effect. In our study, highly significant $(\mathrm{P} \leq 0.001)$ increasing of MGT was observed by the application of various aqueous rice extract on the six weed species (Figure 2). But the MGT increasing rates were variable due to the differences in rice culti-

Table 1. Mean germination with germination reduction percentage of different weeds after treatment application.

\begin{tabular}{|c|c|c|c|c|c|c|c|}
\hline Weed spp. & Control & $\begin{array}{c}\text { T1 } \\
\text { (WITA-3) }\end{array}$ & $\begin{array}{c}\text { T2 } \\
(\text { WITA-4) }\end{array}$ & $\begin{array}{c}\text { T3 } \\
\text { (WTA-12) }\end{array}$ & $\begin{array}{c}\mathrm{T} 4 \\
(\mathrm{~W} 00-\mathrm{CO})\end{array}$ & $\begin{array}{c}\text { T5 } \\
\text { (Fukuhibiki) }\end{array}$ & $\begin{array}{c}\text { T6 } \\
\text { (Kalizira) }\end{array}$ \\
\hline Weedy rice & $20.0 \pm 0.0^{\mathrm{a}}$ & $\begin{array}{c}17.67 \pm 1.5^{\mathrm{a}} \\
\quad(11.65)\end{array}$ & $\begin{array}{c}19.33 \pm 1.15^{\mathrm{a}} \\
\quad(3.35)\end{array}$ & $\begin{array}{l}18.67 \pm 1.52^{\mathrm{a}} \\
\quad(6.65)\end{array}$ & $\begin{array}{c}19.66 \pm 0.58^{\mathrm{a}} \\
(1.70)\end{array}$ & $\begin{array}{c}19.0 \pm 1.0^{\mathrm{a}} \\
(5.0)\end{array}$ & $\begin{array}{c}18.67 \pm 1.5^{\mathrm{a}} \\
\quad(6.65)\end{array}$ \\
\hline Cyperus difformis & $19.0 \pm 1.0^{\mathrm{a}}$ & $\begin{array}{c}9.66 \pm 1.15^{b} \\
(49.16)\end{array}$ & $\begin{array}{c}11.0 \pm 2.0^{\mathrm{b}} \\
(42.11)\end{array}$ & $\begin{array}{c}7.67 \pm 1.53^{b} \\
(59.63)\end{array}$ & $\begin{array}{c}17.0 \pm 1.0^{b} \\
(10.53)\end{array}$ & $\begin{array}{c}13.0 \pm 2.0^{b} \\
(31.58)\end{array}$ & $\begin{array}{c}9.0 \pm 1.52^{b} \\
(52.63)\end{array}$ \\
\hline Echinochloa crus-galli & $14.0 \pm 1.0^{\mathrm{b}}$ & $\begin{array}{c}9.33 \pm 2.51^{\mathrm{b}} \\
(33.36)\end{array}$ & $\begin{array}{c}6.33 \pm 2.08^{c} \\
(54.79)\end{array}$ & $\begin{array}{c}7.0 \pm 1.0^{b} \\
(50.0)\end{array}$ & $\begin{array}{c}10.0 \pm 1.0^{c} \\
(28.57)\end{array}$ & $\begin{array}{c}6.33 \pm 2.52^{c} \\
(54.79)\end{array}$ & $\begin{array}{c}8.33 \pm 0.58^{b} \\
(40.50)\end{array}$ \\
\hline Cyperus iria & $14.6 \pm 1.5^{\mathrm{bc}}$ & $\begin{array}{c}0.0 \pm 0.0^{c} \\
(100)\end{array}$ & $\begin{array}{c}0.0 \pm 0.0^{\mathrm{d}} \\
(100)\end{array}$ & $\begin{array}{c}0.0 \pm 0.0^{c} \\
(100)\end{array}$ & $\begin{array}{c}0.0 \pm 0.0^{\mathrm{d}} \\
(100)\end{array}$ & $\begin{array}{c}0.0 \pm 0.0^{\mathrm{d}} \\
(100)\end{array}$ & $\begin{array}{c}0.0 \pm 0.0^{c} \\
(100)\end{array}$ \\
\hline Fimbristylis milliacea & $13.0 \pm 2.0^{c}$ & $\begin{array}{c}9.67 \pm 1.52^{\mathrm{b}} \\
(25.62)\end{array}$ & $\begin{array}{c}8.33 \pm 0.58^{c} \\
(35.92)\end{array}$ & $\begin{array}{c}6.66 \pm 1.52^{\mathrm{b}} \\
(48.77)\end{array}$ & $\begin{array}{c}9.0 \pm 2.0^{c} \\
(30.77)\end{array}$ & $\begin{array}{c}10.0 \pm 1.0^{b} \\
(23.08)\end{array}$ & $\begin{array}{c}9.67 \pm 2.08^{b} \\
(25.62)\end{array}$ \\
\hline Mean & $16.13^{\mathrm{a}}$ & $\begin{array}{c}9.27^{c} \\
(42.56)\end{array}$ & $\begin{array}{l}8.99 \mathrm{de} \\
(44.22)\end{array}$ & $\begin{array}{c}8^{e} \\
(50.41)\end{array}$ & $\begin{array}{l}11.13^{b} \\
(30.99)\end{array}$ & $\begin{array}{l}9.67 \mathrm{bc} \\
(40.08)\end{array}$ & $\begin{array}{c}9.13^{\mathrm{d}} \\
(43.38)\end{array}$ \\
\hline
\end{tabular}

${ }^{\mathrm{a}-\mathrm{e}}$ Mean values and $\pm \mathrm{SE}$ with different lower case letters in a row are significantly different at $\mathrm{P}<0.001$. Values in the parentheses indicate percentage reduction compared to control treatment.

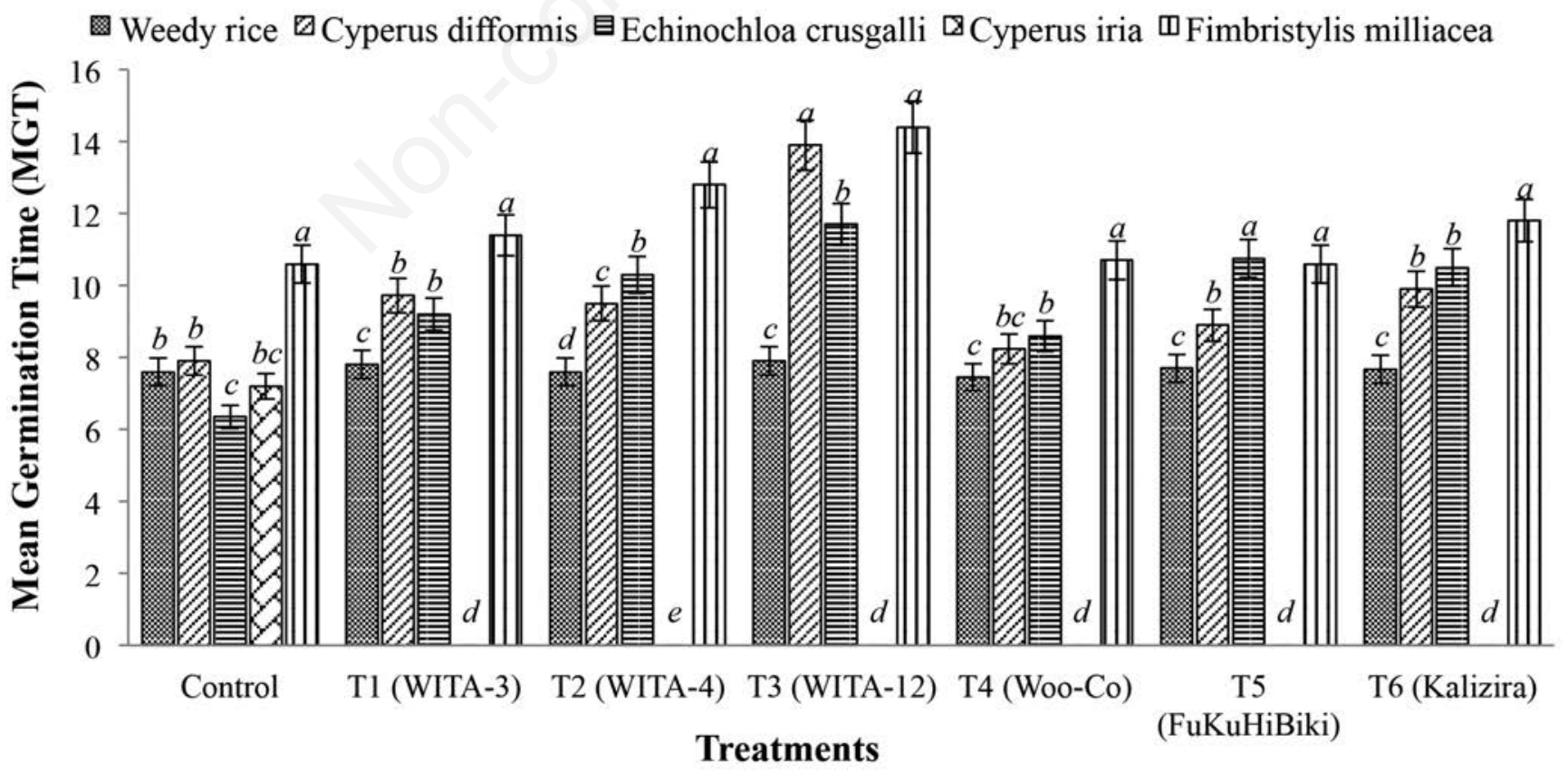

Figure 2. Effect of rice aqueous extract on mean germination time (MGT) of the weed species. Means with different lower case letters within groups are significantly different at $\mathrm{P}<0.001$. 
vars and their allelochemical potentialities. In control treatments, Fimbristylis milliacea took the longest time (10.6 days) to germinate followed by Cyperus difformis (7.9 days), weedy rice (7.6 days), Cyperus iria (7.2 days) and Echinochloa crus-galli (6.35 days) respectively (Figure 2). After treatment application, the longest delay in MGT (14.4 days) was recorded in Fimbristylis milliacea exerted by T3 (WITA-12) followed by 13.9 days in case of Cyperus difformis at the same treatment. But Cyperus iria weed species showed complete failure to germinate at all the treatments except control. Whereas for weedy rice, no significant variation in MGT was observed in any treatments compared to control. However, for other weed species; significant and consecutive increases in MGT were noted in case of all the treatments (Figure 2). Our findings are in agreement with Kabir et al. (2010) who reported about $50 \%$ and $30.8 \%$ increase in MGT of spinach by the effect of rice aqueous extract of WITA-12 and WITA-3 rice cultivars respectively.

\section{Time to $50 \%$ germination}

Time to $50 \%$ germination of the five weed species under different treatments is presented in Table 2. In general, the time to $50 \%$ germination increased with the different treatment effects of six rice aqueous extract in all weeds species compared to control. The longest time to $50 \%$ germination (13.3 days) was found in Fimbristylis milliacea with T3 (WITA-12) followed by 12.9 days in Cyperus difformis with the same treatment. Whereas the lowest time to $50 \%$ germination (6.3 days) was recorded in weedy rice with T2 (WITA-4) and T5 (Fukuhibiki) respectively, except con- trol. Fimbristylis milliacea was recorded with the longest time to $50 \%$ germination for all the six treatments compared to other weed species (Table 2). Considering all the six treatments for time to $50 \%$ germination over weed species, the highest allelopathic effect was observed in T3 (WITA-12) followed by T2 (WITA-4) and the lowest effect to $50 \%$ germination time was found at T4 (Woo-Co) compared to all other treatments (Table 2). Babar et al. (2009) reported that the allelopathic effect of wild onion (Asphodelus tenuifolius) increased $15-30 \%$ more time to $50 \%$ germination of chickpea (Cicer arietinum) seeds compared to control treatments. Karim et al. (2014) also reported that on an average more than $30 \%$ time was required to $50 \%$ germination of Echinochloa crusgalli weed seeds by the allelopathic effect of aqueous extract of WITA-3, WITA-12, WITA-8 and Woo-Co rice cultivars. Significant $(\mathrm{P} \leq 0.001)$ interaction between weed species and rice extracts was observed on germination of all weed seeds under study indicating allelopathic inhibition was species specific.

\section{Shoot and root length}

The seedling shoot and root lengths have been the most frequently used parameters for the expression of allelopathic potential (Khaliq et al., 2013). In this study shoot length of all weed species declined at all the six treatments compared to control but shoot lengths varied depending on differences in weeds species (Table 3). Among all the weeds species, weedy rice produced the longest shoot length $(50 \mathrm{~mm})$ in control treatment as well as in other treatments compared to any other weed species (Table 3 ). Among other weed species, the highest shoot length $(38.4 \mathrm{~mm})$ was produced by Echinochloa crus-galli in control treatments but significant

Table 2. Rice allelopathic effect on time (days) to $50 \%$ germination of different weed species.

\begin{tabular}{|c|c|c|c|c|c|c|c|}
\hline Weed spp. & Control & $\begin{array}{c}\text { T1 } \\
\text { (WITA-3) }\end{array}$ & $\begin{array}{c}\text { T2 } \\
(\text { WITA-4) }\end{array}$ & $\begin{array}{c}\text { T3 } \\
\text { (WITA-12) }\end{array}$ & $\begin{array}{c}\mathrm{T4} \\
(\mathrm{WOO}-\mathrm{CO})\end{array}$ & $\begin{array}{c}\text { T5 } \\
\text { (Fukuhibiki) }\end{array}$ & $\begin{array}{c}\mathrm{T6} \\
\text { (Kalivira) }\end{array}$ \\
\hline Weedy rice & $6.2 \pm 0.37^{\mathrm{b}}$ & $7.06 \pm 0.16^{c}$ & $6.3 \pm 0.42^{\mathrm{d}}$ & $6.45 \pm 0.65^{c}$ & $6.35 \pm 0.85^{c}$ & $6.3 \pm 0.67^{c}$ & $6.45 \pm 0.7^{\mathrm{d}}$ \\
\hline Cyperus difformis & $6.94 \pm 0.6^{\mathrm{b}}$ & $8.42 \pm 0.5^{b}$ & $8.1 \pm 0.31^{c}$ & $12.9 \pm 0.47^{\mathrm{a}}$ & $7.0 \pm 0.26^{\mathrm{bc}}$ & $7.8 \pm 0.47^{\mathrm{b}}$ & $8.42 \pm 0.2^{c}$ \\
\hline Echinochloa crusgalli & $5.21 \pm 0.5^{c}$ & $8.0 \pm 0.43^{b}$ & $9.8 \pm 0.37^{b}$ & $10.2 \pm 0.33^{b}$ & $7.5 \pm 0.48^{b}$ & $9.8 \pm 1.0^{\mathrm{a}}$ & $9.1 \pm 0.41^{b}$ \\
\hline Cyperus iria & $6.3 \pm 0.42^{b}$ & $0.0 \pm 0.0^{\mathrm{d}}$ & $0.0 \pm 0.0^{\mathrm{e}}$ & $0.0 \pm 0.0^{\mathrm{d}}$ & $0.0 \pm 0.0^{\mathrm{d}}$ & $0.0 \pm 0.0^{\mathrm{d}}$ & $0.0 \pm 0.0^{\mathrm{e}}$ \\
\hline Fimbristylis milliacea & $8.9 \pm 0.86^{\mathrm{a}}$ & $10.20 \pm 0.6^{\mathrm{a}}$ & $11.90 \pm 0.4^{\mathrm{a}}$ & $13.3 \pm 0.44^{\mathrm{a}}$ & $9.7 \pm 0.45^{\mathrm{a}}$ & $9.4 \pm 0.60^{\mathrm{a}}$ & $10.2 \pm 0.5^{\mathrm{a}}$ \\
\hline
\end{tabular}

a-e Mean values and \pm SE with different lower case letters in a row are significantly different at $\mathrm{P}<0.001$.

Table 3. Mean shoot length $(\mathrm{mm})$ with percentage reduction of different weeds after treatment application.

\begin{tabular}{|c|c|c|c|c|c|c|c|}
\hline Weed spp. & Control & $\begin{array}{c}\text { T1 } \\
\text { (WITA-3) }\end{array}$ & $\begin{array}{c}\text { T2 } \\
(\text { WITA-4) }\end{array}$ & $\begin{array}{c}\text { T3 } \\
\text { (WITA-12) }\end{array}$ & $\begin{array}{c}\mathrm{T} 4 \\
(\mathrm{~W} 00-\mathrm{CO})\end{array}$ & $\begin{array}{c}\text { T5 } \\
\text { (Fukuhibiki) }\end{array}$ & $\begin{array}{c}\text { T6 } \\
\text { (Kalizira) }\end{array}$ \\
\hline Weedy rice & $50.0 \pm 2.5^{\mathrm{a}}$ & $\begin{array}{l}47.0 \pm 2.0^{\mathrm{a}} \\
(6)\end{array}$ & $\begin{array}{l}50.0 \pm 2.0^{\mathrm{a}} \\
(0)\end{array}$ & $\begin{array}{c}48.0 \pm 2.64^{\mathrm{a}} \\
\text { (4) }\end{array}$ & $\begin{array}{c}48.0 \pm 3.0^{\mathrm{a}} \\
(4)\end{array}$ & $\begin{array}{c}47.33 \pm 3.5^{\mathrm{a}} \\
(5.34)\end{array}$ & $\begin{array}{c}48.3 \pm 4.5^{\mathrm{a}} \\
(3.34)\end{array}$ \\
\hline Cyperus difformis & $11.43 \pm 0.6^{\mathrm{cd}}$ & $\begin{array}{c}9.66 \pm 0.35^{c} \\
(15.45)\end{array}$ & $\begin{array}{c}8.79 \pm 0.76^{c} \\
(23.09)\end{array}$ & $\begin{array}{c}6.86 \pm 0.60^{c} \\
(39.98)\end{array}$ & $\begin{array}{c}10.5 \pm 0.65^{c} \\
(8.14)\end{array}$ & $\begin{array}{l}10.66 \pm 1.15^{c} \\
(6.74)\end{array}$ & $\begin{array}{c}7.53 \pm 0.67^{c} \\
(34.12)\end{array}$ \\
\hline Echinochloa crusgalli & $38.4 \pm 0.9^{b}$ & $\begin{array}{c}35.5 \pm 1.60^{\mathrm{b}} \\
(7.55)\end{array}$ & $\begin{array}{c}33.67 \pm 1.7^{\mathrm{b}} \\
(12.32)\end{array}$ & $\begin{array}{l}29.17 \pm 2.66^{\mathrm{b}} \\
\quad(24.04)\end{array}$ & $\begin{array}{l}31.53 \pm 2.38^{b} \\
(17.89)\end{array}$ & $\begin{array}{c}26.80 \pm 2.32^{\mathrm{b}} \\
(30.21)\end{array}$ & $\begin{array}{c}27.2 \pm 1.9^{b} \\
(29.17)\end{array}$ \\
\hline Cyperus iria & $12.3 \pm 1.2^{\mathrm{c}}$ & $\begin{array}{c}0.0 \pm 0.0^{\mathrm{d}} \\
(100)\end{array}$ & $\begin{array}{c}0.0 \pm 0.0^{\mathrm{d}} \\
(100)\end{array}$ & $\begin{array}{c}0.0 \pm 0.0^{\mathrm{d}} \\
(100)\end{array}$ & $\begin{array}{c}0.0 \pm 0.0^{\mathrm{d}} \\
(100)\end{array}$ & $\begin{array}{c}0.0 \pm 0.0^{\mathrm{e}} \\
(100)\end{array}$ & $\begin{array}{c}0.0 \pm 0.0^{\mathrm{e}} \\
(100)\end{array}$ \\
\hline Fimbristylis milliacea & $8.93 \pm 0.6^{\mathrm{d}}$ & $\begin{array}{c}7.67 \pm 0.35^{c} \\
(14.11)\end{array}$ & $\begin{array}{c}7.4 \pm 0.62^{c} \\
(17.13)\end{array}$ & $\begin{array}{c}6.33 \pm 0.47^{c} \\
(29.12)\end{array}$ & $\begin{array}{c}8.23 \pm 0.31^{\mathrm{c}} \\
(7.84)\end{array}$ & $\begin{array}{c}5.33 \pm 0.45^{\mathrm{d}} \\
\quad(40.31)\end{array}$ & $\begin{array}{c}8.77 \pm 0.6^{\mathrm{d}} \\
(1.79)\end{array}$ \\
\hline Mean & $24.22^{\mathrm{a}}$ & $\begin{array}{c}19.97^{\mathrm{b}} \\
(17.56)\end{array}$ & $\begin{array}{c}19.97^{b} \\
(17.53)\end{array}$ & $\begin{array}{c}18.07 \\
(25.38)\end{array}$ & $\begin{array}{c}19.65^{b} \\
(18.85)\end{array}$ & $\begin{array}{l}18.02^{\mathrm{bc}} \\
(25.58)\end{array}$ & $\begin{array}{c}18.37^{c} \\
(24.16)\end{array}$ \\
\hline
\end{tabular}

\footnotetext{
${ }^{\text {a-e }}$ Mean values and \pm SE with different lower case letters in a row are significantly different at $\mathrm{P}<0.001$. Values in the parentheses indicate percentage reduction compared to control treatment.
} 
$(\mathrm{P} \leq 0.001)$ reductions in shoot lengths were observed at all the treatments effect of aqueous rice extract with the highest reduction (26.80 mm, 30.21\%) at T5 (Fukuhibiki) and the lowest shoot reduction $(35.5 \mathrm{~mm}, 7.55 \%)$ noted at $\mathrm{T} 1$ (WITA-1) compared to control (Table 3). While among all the treatments the highest shoot reduction (39.98\%) was observed in case of Cyperus difformis at T3 (WITA-12) and the lowest shoot reduction (1.79\%) was noted in Fimbristylis milliacea at T6 (Kalizira) compared to control (Table 3). Several scientists have also reported similar research findings. Kabir et al. (2010) reported about 40-50\% shoot length reduction in spinach by the effect of allelopathic aqueous extract of WITA-3 and WITA-12 rice cultivars. The highest shoot length reduction $(37.18 \%)$ in lettuce has been described by Karim et al. (2012) by the allelopathic effect of several rice cultivars developed by BRRI, Bangladesh.

Root lengths of all the weed species were also significantly $(\mathrm{P}<0.001)$ affected by the allelopathic effect of aqueous extract of six rice varieties compared to control. However, in our experiment; less root lengths reduction was observed over shoot lengths reduction (Table 4). In case of weedy rice, root length reductions were not significant for all the six treatments as were observed for shoot length. While for all other weed species, varied root length reductions were seen in all the six treatments (Table 4). The highest root length reduction (37.97\%) was recorded with T5 (Fukuhibiki) in Fimbristylis milliacea followed by $35.44 \%$ reduction with T3 (WITA-12) in case of Cyperus difformis and the least root length reduction (only $0.36 \%$ ) was found in weedy rice at T1 (WITA-3) compared to control (Table 4). Considering other weeds (except weedy rice) only $1.91 \%$ root length reduction was observed in Cyperus difformis at T4 (Woo-Co) compared to control (Table 4). On an average, among all six aqueous extract treatments T3 (WITA-12) showed the highest root length reduction (23.04\%) followed by, T5 (Fukuhibiki, 22.27\%), T6 (Kalizira, 22.20\%), T2 (WITA-4, 18.46\%), T4 (Woo-Co, 17.14\%) and T1 (WITA-3, $15.74 \%$ ) respectively, over control (Table 4). In agreement with our findings, Karim et al. (2014) reported that WITA-12 and WooCo rice aqueous extract caused more than $80 \%$ root length reduction of Echinochloa crus-galli weed. On the other hand, Karim et al. (2012) observed $38.81 \%$ root length reduction of lettuce by the allelopathic effect of other rice varieties of BRRI, Bangladesh. Furthermore, Kabir et al. (2010) reported that, the allelopathic effect of the rice cultivar WITA-12 caused about $60 \%$ root length reduction of spinach. In another study, by Karim and Ismail (2007) observed that rice varieties namely Manik and Makmuer caused more than $80 \%$ and $75 \%$ reduction of root length of E. crus-galli, respectively due to their allelopathic effect.

Reduced root and shoot lengths of test weed species can be due to alterations in DNA synthesis in their respective apical meristem's, mitochondrial metabolism (Denise et al., 2000) or changes in cell mitotic indices (Khaliq et al., 2013) or a combination of all of them. Al-Wakeel et al. (2007) reported that retarded seedling elongation might be an outcome of the direct interference of allelochemicals with the process of cell division that alters the balance of different growth hormones. Differences in the activity of different extracts in suppressing the seedling growth of the tested weed species may be due to differences in the type and concentration of allelochemicals present in these extracts (Xuan et al., 2005).

\section{Conclusions}

In this study, all the tested rice varieties showed significant allelopathic influences on weed growth and the variety WITA-12 (T3) had the highest potential than others. More importantly, WITA-12 exhibited the highest allopathic activities on both germination and shoot-root growth. While other rice varieties exhibited different trends; such as for germination inhibition; $\mathrm{T} 3>\mathrm{T} 2>\mathrm{T} 6>\mathrm{T} 1>\mathrm{T} 5>\mathrm{T} 4$, for shoot length reduction; $\mathrm{T} 3>\mathrm{T} 5>\mathrm{T} 6>\mathrm{T} 4>\mathrm{T} 1>\mathrm{T} 2$ and for root length reduction the trend was $\mathrm{T} 3>\mathrm{T} 5>\mathrm{T} 6>\mathrm{T} 2>\mathrm{T} 4>\mathrm{T} 1$ respectively. From these findings, we propose that different rice varieties contain allelochemicals that vary in type and concentration whereas the tolerance capabilities in weeds species were also different so for this the performance of rice cultivars on weed species varied significantly. Based on overall performances of all the rice varieties we can select four varieties namely WITA-12, WITA-4, Fukuhibiki and Kalizira as gene resources for further researches towards breeding for allelopathic potentiality and can be incorporated with high yielding rice varieties to generate allelopathic high yielding rice. For greater achievements, genes responsible for controlling this effect should be found; mapped and new transgenic crops with allelopathic properties should be developed.

Table 4. Mean root lengths $(\mathrm{mm})$ with percentage reduction of different weeds after treatment application.

\begin{tabular}{|c|c|c|c|c|c|c|c|}
\hline Weed spp. & Control & $\begin{array}{c}\text { T1 } \\
\text { (WITA-3) }\end{array}$ & $\begin{array}{c}\text { T2 } \\
(\text { WITA-4) }\end{array}$ & $\begin{array}{c}\text { T3 } \\
\text { (WITA-12) }\end{array}$ & $\begin{array}{c}\mathrm{T} 4 \\
(\mathrm{~W} 00-\mathrm{CO})\end{array}$ & $\begin{array}{c}\text { T5 } \\
\text { (Fukuhibiki) }\end{array}$ & $\begin{array}{c}\text { T6 } \\
\text { (Kalizira) }\end{array}$ \\
\hline Weedy rice & $47.27 \pm 0.7^{\mathrm{a}}$ & $\begin{array}{l}47.1 \pm 0.65^{\mathrm{a}} \\
(0.36)\end{array}$ & $\begin{array}{c}46.4 \pm 0.87^{\mathrm{a}} \\
(1.84)\end{array}$ & $\begin{array}{c}46.23 \pm 1.07^{\mathrm{a}} \\
(2.2)\end{array}$ & $\begin{array}{l}46.10 \pm 1.47^{\mathrm{a}} \\
(2.47)\end{array}$ & $\begin{array}{l}46.13 \pm 1.25^{\mathrm{a}} \\
\quad(2.41)\end{array}$ & $\begin{array}{c}46.38 \pm 0.7^{\mathrm{a}} \\
(1.88)\end{array}$ \\
\hline Cyperus difformis & $9.96 \pm 1.17^{\mathrm{d}}$ & $\begin{array}{c}8.6 \pm 0.40^{c} \\
(13.65)\end{array}$ & $\begin{array}{c}8.16 \pm 0.96^{\mathrm{c}} \\
(18.07)\end{array}$ & $\begin{array}{c}6.43 \pm 0.67^{\mathrm{c}} \\
(35.44)\end{array}$ & $\begin{array}{c}9.77 \pm 0.58^{c} \\
(1.91)\end{array}$ & $\begin{array}{c}9.56 \pm 0.59^{c} \\
(4.02)\end{array}$ & $\begin{array}{c}6.96 \pm 0.61^{\mathrm{c}} \\
(30.12)\end{array}$ \\
\hline Echinochloa crusgalli & $31.73 \pm 1.3^{b}$ & $\begin{array}{c}30.96 \pm 1.1^{b} \\
(2.43)\end{array}$ & $\begin{array}{c}29.50 \pm 0.50^{b} \\
(7.03)\end{array}$ & $\begin{array}{c}27.53 \pm 1.38^{b} \\
\quad(13.24)\end{array}$ & $\begin{array}{l}29.13 \pm 2.59^{b} \\
\quad(8.19)\end{array}$ & $\begin{array}{c}25.86 \pm 1.64^{b} \\
(18.49)\end{array}$ & $\begin{array}{c}25.26 \pm 2.4^{b} \\
(20.39)\end{array}$ \\
\hline Cyperus iria & $14.33 \pm 0.6^{c}$ & $\begin{array}{c}0.0 \pm 0.0^{\mathrm{e}} \\
(100)\end{array}$ & $\begin{array}{c}0.0 \pm 0.0^{\mathrm{e}} \\
(100)\end{array}$ & $\begin{array}{c}0.0 \pm 0.0^{\mathrm{d}} \\
(100)\end{array}$ & $\begin{array}{c}0.0 \pm 0.0^{\mathrm{d}} \\
(100)\end{array}$ & $\begin{array}{c}0.0 \pm 0.0^{\mathrm{e}} \\
(100)\end{array}$ & $\begin{array}{l}0.0 \pm 0.0^{\mathrm{d}} \\
(100)\end{array}$ \\
\hline Fimbristylis milliacea & $8.06 \pm 0.40^{\mathrm{e}}$ & $\begin{array}{c}7.16 \pm 0.30^{\mathrm{d}} \\
(11.17)\end{array}$ & $\begin{array}{c}6.73 \pm 0.58^{\mathrm{d}} \\
\quad(16.50)\end{array}$ & $\begin{array}{c}5.50 \pm 0.56^{\mathrm{c}} \\
(31.76)\end{array}$ & $\begin{array}{c}7.26 \pm 0.65^{\mathrm{c}} \\
(9.93)\end{array}$ & $\begin{array}{c}5.0 \pm 0.10^{\mathrm{d}} \\
(37.97)\end{array}$ & $\begin{array}{c}8.03 \pm 0.47^{c} \\
(0.37)\end{array}$ \\
\hline Mean & $22.27^{\mathrm{a}}$ & $\begin{array}{c}18.76^{b} \\
(15.74)\end{array}$ & $\begin{array}{l}18.16^{\mathrm{bc}} \\
(18.46)\end{array}$ & $\begin{array}{l}17.14^{c} \\
(23.04)\end{array}$ & $\begin{array}{l}18.45^{\mathrm{bc}} \\
(17.14)\end{array}$ & $\begin{array}{c}17.31^{\mathrm{c}} \\
(22.27)\end{array}$ & $\begin{array}{c}17.33^{\mathrm{c}} \\
(22.20)\end{array}$ \\
\hline
\end{tabular}

ae-e Mean values and \pm SE with different lower case letters in a row are significantly different at $\mathrm{P}<0.001$. Values in the parentheses indicate percentage reduction compared to control treatment. 


\section{References}

Abouziena HF, Haggag WM, 2016. Weed control in clean agriculture: a review. Planta Daninha. 34:377-92.

Al-Wakeel SAM, Gabr MA, Hamid AA, 2007. Allelopathic effects of Acacia nilotica leaf residue on Pisum sativum L. Allelopathy J. 19:411-22.

Amb MK, Ahluwalia AS, 2016. Allelopathy: potential role to achieve new milestones in rice cultivation. Rice Sci. 23:165-83.

Asghari J, Berendji S, Matin AA, Fotoohi H, Sharifi MM, 2006. Potential allelopathic effects of rice (Oryza sativa) hull extracts on barnyardgrass (Echinochloa crusgalli) seedling growth. Iranian J. Weed Sci. 2:31-44.

Aslani F, Juraimi AS, Ahmad-Hamdani MS, Alam MA, Omar D, Hakim MA, 2015. Phytotoxic interference of volatile organic compounds and water extracts of Tinospora tuberculata Beumee on growth of weeds in rice fields. South African J. Bot. 100:132-40.

Aslani F, Juraimi AS, Ahmad-Hamdani MS, Omar D, Alam MA, Hashemi FSG, Hakim MA, Uddin MK, 2014. Allelopathic effect of methanol extracts from Tinospora tuberculata on selected crops and rice weeds. Acta Agri. Scan. Sec. B Soil Plant Sci. 64:165-77.

Azmi M, Mashhor M, 1995. Weed succession from transplanting to direct-seeding method in Kemubu rice area, Malaysia. J. Biosci. 6:143-54.

Babar BH, Tanveer A, Tahir M, Aziz A, Ahmad AUH, Nadeem MA, Javaid MM, 2009. Allelopathic potential of wild onion (Asphodelus tenuifolius) on the germination and seedling growth of chickpea (Cicer arietinum). Weed Biol. Manag. 9:146-51.

Bi HH, Zeng RS, Su LM, An M, Luo SM, 2007. Rice allelopathy induced by methyl jasmonate and methyl salicylate. J. Chem. Ecol. 35:1089-103.

Cheng F, Cheng Z, 2015. Research progress on the use of plant allelopathy in agriculture and the physiological and ecological mechanisms of allelopathy. Front. Plant Sci. 6:1-16.

Chopra M, Tewari G, Tewari LM, Upreti B, Pandey N, 2017. Allelopathic effect of Echinochloa colona L. and Cyperus iria L. weed extracts on the seed germination and seedling growth of rice and soyabean. Advan. Agric. 2017:1-5.

Denise A, Welligton LB, Ana MK, Emy LI, 2000. Effects of four monoterpenes on germination, primary root growth, and mitochondrial respiration of maize. J. Chem. Ecol. 26:611-24.

Duke SO, Dayan FE, Romagni JG, Rimando AM, 2000. Natural products as sources of herbicides: current status and future trends. Weed Res. 40:99-111.

Ellis RA, Roberts, 1981. The qualification of ageing and survival in orthodox seeds. Seed Sci. Technol. 9:373-409.

FAOSTAT, 2012. Available from: http://www.fao.org/docrep/015/ i2490e/i2490e00.htm

Farooq M, Basra SMA, Rehman H, Mehmood T, 2006. Germination and Early seedling growth as affected by pre-sowing ethanol seed treatments in fine rice. Int. J. Agric. Biol. 8:19-22.

Guo L, Qiu J, Ye C, Jin G, Mao L, Zhang H, Yang X. 2017. Echinochloa crus-galli genome analysis provides insight into its adaptation and invasiveness as a weed. Nat Commun. 8:1031-41.

Hakim MA, Juraimi AS, Hanafi MM, Ismail MR, Rafii MY, Aslani F, Selamat A. 2014. Integration of herbicides with manual weeding for controlling the weeds in rice under saline environment. J. Environ. Biol. 36:1311-7.

Holethi SM, Aidy IR, Bastawisi AO, Draz AE, 1998. Weed management using allelopathic rice varieties in Egypt. In: M.
Olofsdotter (Ed.), Allelopathy in rice. International Rice Research Institute, Manila, pp. 27-37.

Hong Z, Ueguchi-Tanaka M, Umemura K, Uozu S, Fujioka S, Takatsuto S, Yoshida S, Ashikari M, Kitano H, Matsuoka M, 2003. A rice brassinosteroid-deficient mutant, ebisu dwarf (d2), is caused by a loss of function of a new member of cytochrome P450. Plant Cell 15:2900-10.

ISTA (International Seed Testing Association). 1999. International rules for seed testing. Seed Sci. Technol. 27:340.

Jabran K, 2017. Rye Allelopathy for weed control. manipulation of allelopathic crops for weed control. Springer, Cham. pp. 49-56.

Jafari L, Ghadiri H, Moradshahi A, 2011. Allelopathic potential of rice (Oryza sativa L.) cultivars on Barnyard Grass (Echinochloa crus-galli). J. Agric. Sci. Technol. B1:853-64.

Kabir AKMS, Karim SMR, Begum M, Juraimi AS, 2010. Allelopathic potential of rice varieties against spinach (Spinacia oleracea). Int. J. Agric. Biol. 12:809-15.

Karim SMR, Ismail BS, 2007. Allelopathic effects of aqeous extracts from rice leaves and decomposing rice debris on the seed germination and growth of barnyard grass (Echinochloa crusgalli L. Beauv.). In: Proc. 21st Asian Pacific Weed Science Society. pp. 275.

Karim SMR, Momin AMTAM, Begum M, 2012. Allelopathic potential of selected rice varieties. African J. Biotechnol. 11:15410-4

Karim SMR, Mridha AJ, Faruq G, 2014. Allelopathic potential of rice cultivars against Echinochloa crusgalli. Int. J. Biol. Pharm. Allied Sci. 3:2027-39.

Kato-Noguchi H, Ota K, Ino T, 2008. Release of momilactone A and $\mathrm{B}$ from rice plants into the rhizosphere and its bioactivities. Allelo. J. 22:321-8.

Khaliq A, Matloob A, Khan MB, Tanveer A, 2013. Differential suppression of rice weeds by allelopathic plant Aqueous extracts. Planta Daninha 31:21-8.

Khush GS, 2005. What it will take to feed 5.0 billion rice consumers in 2030? Plant Mol. Biol. 59:1-6.

Ministry of Agriculture, 2007. Buku perangkaan pertanian 2007. Unit penerbitan, Putrajaya, Malaysia.

Naderi R, Bijanzadeh E, 2012. Allelopathic potential of leaf, stem and root extracts of some Iranian rice (Oryza sativa L.) cultivars on barnyardgrass (Echinochloa crus-galli) growth. Plant Knowledge J. 1:37-40.

Naylor R (Ed.), 1996. Herbicides in Asian rice: transitions in weed management. Palo Alto (California): Institute for International Studies, Stanford University and Manila (Philippines): International Rice Research Institute, pp. 270

Rao AN, Johnson DE, Sivaprasad B, Ladha JK, Mortimer AM, 2007. Weed management in direct-seeded rice. Adv. Agron. 93:153-255.

SAS, 2013. The SAS system for Windows, version 9.3 (TS1M2). SAS Institute Inc., Cary, NC, USA.

Tabaglio V, Gavazzi C, Schulz M, Marocco A, 2008. Alternative weed control using the allelopathic effect of natural benzoxazinoids from rye mulch. Agron. Sust. Develop. 28:397-401.

Trezzi MM, Vidal RA, Junior AAB, Bittencourt HH, Filho APSS, 2016. Allelopathy: driving mechanisms governing its activity in agriculture. J. Plant Interac. 11:53-60.

Xuan TD, Tawata S, Khanh TD, 2005. Biological control of weeds and plant pathogens in paddy fields by exploiting plant allelopathy: an overview. Crop Prot. 24:197-206. 